\title{
Economic Analysis of the Integrated Operation Mode of Nuclear Power Station and Pumped-storage Power Station
}

\author{
Cai-qing $\mathrm{ZHANG}^{1,{ }^{*}, \mathrm{Mi} \mathrm{ZHANG}^{1} \text { and Yu-ping LIU }}{ }^{1}$ \\ ${ }^{1}$ Department of Economics and Management, North China Electric Power University, \\ Baoding 071003, China
}

Keywords: Integrated operation mode of nuclear power station and pumped-storage power station, Economy, Cost comparison method.

\begin{abstract}
This paper proposes the integrated operation mode of nuclear power station and pumped-storage power station, and makes an intensive economic analysis of the integrated operation mode based on the position of investors. Firstly, this paper thoroughly discussed the calculation method of annual cost in two schemes: (a) investors only operate nuclear power station and pay peak load regulation compensation; (b) investors operate nuclear power station and pumped-storage power station jointly to participate in electricity network load adjustment. And cost comparison method was used to compare the economy of two schemes. Secondly, this paper took a nuclear power investor's two operation schemes as an example, and compared the annual cost of each scheme. Ultimately, the case study shows that: the annual cost of integrated operation mode is lower than the annual cost of peak load regulation compensation borne by nuclear power investor, that is to say, the integrated operation mode of nuclear power station and pumped-storage power station is more economical.
\end{abstract}

\section{Introduction}

With the adjustment of the industrial structure, the rapid growth of China's electric power load and the gradual wideness of peak-valley difference have brought greater pressure to the power network operation. Meanwhile, the large scale construction and successional plunging into operation of nuclear power station around the country causes great impact on power network. In order to ensure power network safety and stable operation, it is increasingly necessary for nuclear power station to participate in electricity network load adjustment.

However, in order to ensure the economy and safety of nuclear power station, nuclear power units, which have been put into operation, generally operate with basic load and rarely involve in load adjustment. Thus, nuclear power station have to find other power sources in cooperation so as to take part in electricity network load adjustment and adapt the electric power market demands. Meanwhile, pumped-storage power units are flexible, reliable, and with double load regulating capacity, can not only adjust peak but also fill the valley. In addition, the pumped-storage power units could not only follow quickly the load changes in the power system but also have the functions of good climbing capacity, and frequency and phrase modulation economically and obvious dynamic operation benefits (such as spinning reservation, accident reservation, phase modulation and frequency regulation). All in all, pumped-storage power station is an ideal power source which can take the task of peak regulation.

Thus, it is nuclear power investors that invest and build pumped-storage power station, and combine units control, dispatching, management, and operation all in one, forming "nuclear power station and pumped-storage power station consortium", to 
make the pumped-storage power station united run with the nuclear power station and participate in power network system dispatch as a group. The integrated operation of the nuclear power with pumped-storage power can improve the peak load regulating ability of the system; thereby enhance the nuclear power accommodation level of the system. It is an ideal operation mode. Therefore, research on the integrated operation mode of nuclear power station and pumped-storage power station has important theory value and practical significance.

By summarizing domestic and foreign related literature material, we found the existing studies mainly focus on the strong load regulating capacity and economy benefits of pumped-storage power, or technical feasibility of the integrated operation mode of pumped-storage power station and other power generations (such as hydropower, thermal power, wind power, etc.). However, the economy of the integrated investment and operation mode of nuclear power station and pumped-storage power station has not yet been studied in depth. Study abroad of pumped-storage power started relatively early, Toshiya Nanahara \& Akira Takimoto (1994)studied the design problem of pumped-storage power station[1], NingLu \& Joe H. Chow(2004)and Tsai Chin-Chu et al.(2009)researched the bidding strategies of pumped-storage power station in a competitive electricity market[2,3]. In recent years, domestic scholars discussed the merits and necessity of pumped-storage power station construction. Chu-sheng Cao(2001)suggested that the adoption of combined development way of pumped-storage power station, nuclear power station, wind power plant etc. is a good development way to help the sustainable development of power system[4]. Xue-liang Wang \& Ji-lai Yu's study (2012) found that the difference between peak-time and valley-time of China's electric power load is increasing and pumped-storage power is an effective means to solve this critical problem [5]. Besides, many scholars explored the technical feasibility of the integrated operation mode of nuclear power station and pumped-storage power station. Jie Zhao, Di-chen Liu, et al.(2011)displayed three combined modes of nuclear power station and pumped-storage power station and concluded that the integrated operation can meet the requirements of peak load following and ensure base-load operation of nuclear power station[6]. Meng-ze Qu (2015)analyzed the fluctuation rule of grid load and the operation characteristics of nuclear power station and pumped-storage power station, and concluded that the grid load fluctuation could be tracked and the electricity quality could be ensured in case of the integrated operation[7].

This paper intends to make an intensive economic analysis of the integrated operation mode of nuclear power station and pumped-storage power station based on the position of investors. Firstly, the analysis and calculation methods are thoroughly discussed. Secondly, the author takes a nuclear power investor's two operation schemes as an example, and compares the annual cost of each scheme. Ultimately, this paper proves that the integrated operation mode is more economical from the financial viewpoint.

\section{Analysis Method}

This paper attempts to calculate the annual cost of scheme A (that is, investors only operate nuclear power station and pay peak load regulation compensation) and the annual cost of scheme B (that is, investors operate nuclear power station and pumped-storage power station jointly to participate in electricity network load adjustment) respectively. Then, the cost comparison method is used to evaluate the economy of each scheme. 
In the calculation and comparison process, we follow these basic assumptions: (1) In both scheme A and scheme B, the initial investment amounts and annual cost of nuclear power station are equal; (2) Analysis are based on the current general power market, namely, the mechanism of electricity price bidding has not been implemented yet and the pool purchase price remains unchanged.

\section{Annual Cost Calculation Model of Scheme A}

When investors only operate nuclear power station, the nuclear power station has to participate in electricity market in following three modes: nuclear power units directly participate in peak load regulation, not participate in peak load regulation but purchase auxiliary service or lease pumped-storage power station from power grid company. Based on the actual operation and cost considerations, investors mainly adopt the second mode, namely, purchase auxiliary service. In this mode, investors only operate nuclear power station and nuclear power units do not participate in peak load regulation directly, but need to compensate for the peak load regulation service by paying peak load regulation compensation fee.

In this scheme, the current economic evaluation method of nuclear power station remains unchanged, and regards peak load regulation compensation as an increase of the total cost. Therefore, the formula of annual cost is shown as the following:

$$
\begin{aligned}
& C_{1}=C_{0}+\triangle C_{1} \\
& C_{0}=\left[\sum_{i=i}^{n}(C O)_{t} \times \frac{1}{(1+i)^{n}}\right] \times\left[\frac{i \times(1+i)^{n}}{(1+i)^{n}-1}\right]=\left[\sum_{i=1}^{n}(C O)_{t} \times(P / F, i, n)\right] \times(A / P, i, n)
\end{aligned}
$$

Among them, $\mathrm{C}_{0}$ represents the annual cost of nuclear power station, $\Delta \mathrm{C}_{1}$ represents the annual cost of peak load regulation compensation, and its value should be calculated in accordance with specific auxiliary service management rules or specific peak load regulation compensation agreement.

\section{Annual Cost Calculation Model of Scheme B}

As mentioned previously, the integrated operation mode of nuclear power station and pumped-storage power station is that, investors not only operate nuclear power station but also invest and build matching pumped-storage power station, to make the pumped-storage power station united run with the nuclear power station and participate in power network system dispatch as a group, to meet the requirements of peak load following and ensure base-load operation of nuclear power station. Thus, the nuclear power units do not need to participate in peak load regulation directly, but need to bear the cost of pumped-storage power station.

In this scheme, nuclear power station operates as original way, and its annual cost keeps relatively steady. We regard the annual cost of pumped-storage power station as an increase of the total cost. Therefore, the formula of the integrated operation mode's annual cost is shown as the following:

$$
\begin{aligned}
& C_{2}=C_{0}+\triangle C_{2}+\triangle C_{3} \\
& \triangle C_{2}=\triangle C_{o c}+\triangle C_{d c}+\triangle C_{o e}
\end{aligned}
$$

Among them, $\mathrm{C}_{0}$ represents the annual cost of nuclear power station, $\Delta \mathrm{C}_{2}$ represents the annual cost of pumped-storage power station, $\Delta \mathrm{C}_{\mathrm{oc}}$ represents the annual running cost of pumped-storage power station, $\Delta \mathrm{C}_{\mathrm{dc}}$ represents the annual 
depreciation cost of pumped-storage power station, $\Delta \mathrm{C}_{\mathrm{oc}}$ represents other annual costs of pumped-storage power station, $\Delta \mathrm{C}_{3}$ represents the annual power loss cost of pumped-storage power station.

\section{Practical Calculation Example Analysis}

\section{Basic Situation of the Practical Calculation Example}

A nuclear power investor established a nuclear power station. The installed capacity of the station is $6656 \mathrm{MW}$, which consists of four 1089MW-scale units and two $1150 \mathrm{MW}$-scale units. And the load factor of the units is $80 \%$, that is, the average runtime of the generating set is $7008(8760 \times 80 \%)$ hours every year. The electric price in connection-grid is 0.43 yuan/KWh, which keeps consistent with national nuclear power benchmark price

In initial operation stage, investors signed "peak load regulation compensation agreement" with power grid company, so that the nuclear power units can operate with basic load and do not participate in peak load regulation directly. According to the agreement, the electricity generated within the units available hours $7008 \mathrm{~h}$ (the load factor of units is $80 \%$ ) can sell to grid at the national nuclear power benchmark price of 0.43 yuan/KWh. However, the electricity generated during the units available hours $7008 \mathrm{~h}-7884 \mathrm{~h}$ (the load factor of units is $80 \%-90 \%$ ) should pay extra cost.

Now investors intend to invest and build a daily regulating pumped-storage power station, so as to united run with the nuclear power station and participate in power network system dispatch as a group. The installed capacity of the station is $1200 \mathrm{MW}$, which consists of four 300MW-scale units, and units design available hours in whole year is $1340 \mathrm{~h}$. The investment of the pumped-storage station is 3500 thousand yuan /MW, and design lifetime of main equipment is 25 years.

\section{Operation Mode}

In this situation, the nuclear power units operate with basic load, the pumped-storage power units make full use of its load regulating capacity, and the "nuclear power station and pumped-storage power station consortium" meets load following with three-section tracking mode.

Taking a local daily load curve as an example, the variation of the curve shows "two peaks-two valleys" type, as shown in fig1, the day minimum load appears at about 4:00 am and the value is about $15600 \mathrm{MW}$, the day maximum load appears at about 11:00 am and the value is about $22400 \mathrm{MW}$. The value of maximum peak-valley load difference reaches about 6800MW.

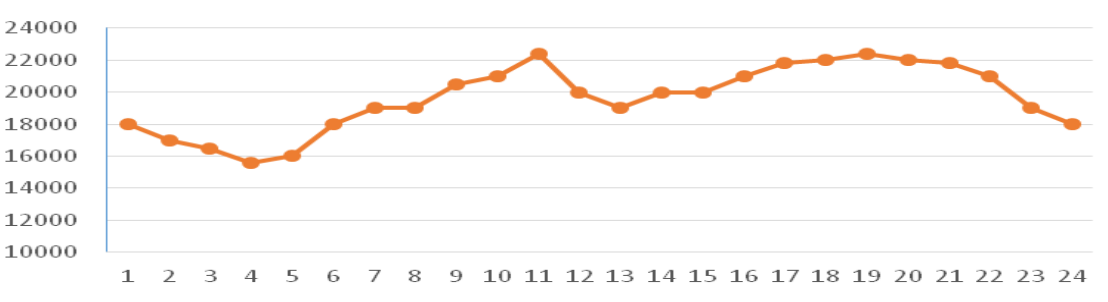

Figure 1. A local daily load curve

In order to adapt to the huge gap between peak and valley, investors put nuclear power station and pumped-storage power station under unified management. All six nuclear power units take generating capacity into full play. Pumped-storage power 
station pumps water in low power consumption time (2:00am-6:00am), generates power in high power consumption time (9:00am-12:00am), and takes the pumped-storage power units' peak-load regulating capacity $( \pm 1200 \mathrm{MW})$ into full play. The basic load of nuclear power station can be down to $5450 \mathrm{MW}$ during the trough time of the network load and up to 7850MW during the peak time. The depth of peak regulation can reach to $30.57 \%$. Daily load curve of the integrated operation is shown in Figure 2.

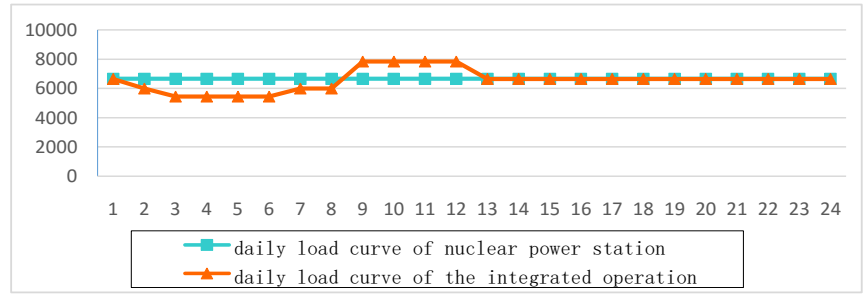

Figure 2. Daily load curve of the integrated operation

\section{Economic Analysis}

By comparing the annual cost calculation models of scheme $\mathrm{A}$ and scheme $\mathrm{B}$, the annual cost of nuclear power station $\left(\mathrm{C}_{0}\right)$ in two schemes is equal. So the annual cost of peak load regulation compensation $\left(\Delta \mathrm{C}_{1}\right)$ and the sum of annual cost of pumped-storage power station $\left(\Delta \mathrm{C}_{2}\right)$ and annual power loss cost of pumped-storage power station should be calculated and compared in this study.

(1) The annual cost of peak load regulation compensation $(\Delta \mathrm{C} 1)$ in scheme $\mathrm{A}$

Investors signed "peak load regulation compensation agreement" with power grid company. The agreement assumed that the load factor of each nuclear power unit generally reaches to $90 \%$, and peak load regulation compensation fee of each nuclear power unit can be calculated on the basis of table 1 .

Table 1. Peak load regulation compensation fee

\begin{tabular}{cccc}
\hline $\begin{array}{c}\text { Units available } \\
\text { hours[h] }\end{array}$ & Load factor & $\begin{array}{c}\text { Peak load regulation } \\
\text { compensation } \\
\text { [thousand yuan] }\end{array}$ & $\begin{array}{c}\text { Generation amount } \\
\text { [thousand MW] }\end{array}$ \\
\hline Under 7008 & $80.00 \%$ & - & - \\
\hline $7008-7300$ & $83.33 \%$ & $12,848.00$ & 298.9 \\
\hline $7300-7600$ & $86.76 \%$ & $26,400.00$ & 307.1 \\
\hline $7600-7884$ & $90.00 \%$ & $44,247.20$ & 290.7 \\
\hline Total & - & $83,495.20$ & 896.7 \\
\hline
\end{tabular}

Therefore, the whole nuclear power station's annual cost of peak load regulation compensation $\left(\Delta \mathrm{C}_{1}\right)$ is:

$$
\Delta \mathrm{C}_{1}=83495.20 \times 6=500971.20 \text { thousand yuan }
$$

(2) The annual cost of pumped-storage power station $\left(\Delta \mathrm{C}_{2}\right)$ in scheme $\mathrm{B}$

According to the actual circumstance of construction and operation of the pumped-storage station, the following information has been obtained: the investment (static) is $3500 y u a n / \mathrm{kW}$; fixed asset formation rate is $100 \%$, straight-line depreciation age is 25 years, residual rate is $5 \%$, thus, annual composite depreciation rate is $3.8 \%$; annual operation cost rate is $2.5 \%$, total of annual other costs rate is $1 \%$. Therefore, the annual cost of pumped-storage power station $\left(\Delta \mathrm{C}_{2}\right)$ is:

$\Delta \mathrm{C}_{2}=3500$ yuan $/ \mathrm{KW} \times 1000 \times 1200 \mathrm{MW} \times(3.8 \%+2.5 \%+1 \%)=306600$ thousand yuan (3) The annual power loss cost of pumped-storage power station $\left(\Delta \mathrm{C}_{3}\right)$ in scheme B 
The pumped-storage power units design available hours in whole year of is $1340 \mathrm{~h}$, comprehensive efficiency is $75 \%$, the electric price in connection-grid is 0.43 yuan/KWh. Therefore, the annual power loss cost of pumped-storage power station $\left(\Delta \mathrm{C}_{3}\right)$ is:

$\Delta \mathrm{C}_{3}=(1200 \mathrm{MW} \times 1340 \mathrm{~h}) \times(1-0.75) \times 0.43 \mathrm{yuan} / \mathrm{KWh} \times 1000=172860$ thousand yuan

The calculation results show that: $\Delta \mathrm{C}_{1}>\Delta \mathrm{C}_{2}+\Delta \mathrm{C}_{3}$, that is, the annual cost of peak load regulation compensation $\left(\Delta \mathrm{C}_{1}\right)$ is higher than the sum of annual cost $\left(\Delta \mathrm{C}_{2}\right)$ and annual power loss cost of pumped-storage power station. So to conclude, the integrated operation mode of nuclear power station and pumped-storage power station is more economical.

In addition, if the pumped-storage power units are fully utilized, the incremental runtime of nuclear power units can be calculated from above results, namely, $(306600+172860) \times 1000 \div(0.43$ yuan $/ \mathrm{KWh} \times 1000) \div 6650 \mathrm{MW}=106.56 \mathrm{~h}$. Therefore, in the scheme of integrated operation mode, the nuclear power station can reach breakeven if only units operate about 106.56 additional hours.

\section{Conclusion}

By using cost comparison method, this paper compared the annual cost of two schemes, and concluded that the integrated operation mode of nuclear power station and pumped-storage power station is more economical. The integrated operation mode can not only meet the demand of electricity network load adjustment, but also ensure the safety and stability of nuclear power station, increase investors' economic benefits. Over all, the integrated operation mode of nuclear power station and pumped-storage power station is feasible and has good development prospect.

\section{References}

[1] Toshiya Nanahara, Akira Takimoto, A study on required reservoir size for pumped hydro storage, IEEE Transactions on Power Systems. 9 (1994) 126-132.

[2] Ning Lu, Joe H. Chow, Alan A. Desroehers, Pumped-storage hydro-turbine bidding strategies in a competitive electricity market, IEEE Transactions on Power Systems. 19 (2004) 834-841.

[3] Tsai Chin-Chu, Cheng Yunzhi, Liang Shun, et al., "The co-optimal bidding strategy of pumped-storage unit in ERCOT energy market", in Proc. 2009 North American Power Symposium, USA, MS, 2009, pp.1-6.

[4] Chu-sheng Cao, The development ways of pumped storage power plant and the power industry development, Water Power. 05 (2001) 1-3.

[5] Xue-liang Wang, Ji-lai Yu, The operation strategy and its benefit assessment of the distributed pumped storage system, Power System Protection and Control. 07 (2012) 129-142.

[6] Jie Zhao, Di-chen Liu, Qing-sheng Lei, et al., Analysis of nuclear power plant participating in peak load regulation of power grid and combined operation with pumped storage power plant, Proceedings of the CSEE,07 (2011) 1-6.

[7] Meng-ze Qu, Combined load tracking with nuclear power station and pumped storage station, Water Power.04 (2015) 66-68. 
[8] Connolly D., Lund H., Finn P., et al., Practical operation strategies for pumped hydroelectric energy storage (PHES) utilizing electricity price arbitrage, Energy Policy. 39 (2011) 4189-4196.

[9] Xiao-hui Wang, Li-zi Zhang, et al., Economic analysis of pumped-storage unit in electricity system with multi-type power sources, Power System Protection and Control. 04 (2014) 8-15. 